Bangladesh J. Bot. 50(3): 903-909, 2021 (September) SpecialＤOI: https://doi.org/10.3329/bjb.v50i5.56443

\title{
EVALUATION AND SCREENING OF LOW PHOSPHORUS STRESS TOLERANCE OF COMMON BEAN (PHASEOLUS VULGARIS L.)
}

\author{
Xiandin Meng*, Qiang Wang, Zhengong Yin, Yifan Guo and Shuhong Wei \\ Crop Resources Institute, Heilongjiang Academy of Agricultural Sciences, \\ Harbin 150086, China
}

Keywords: Common bean, Low-phosphorus stress, Evaluation index, Coefficient of variation

\begin{abstract}
A field experiment was carried out to screen low phosphorus tolerance indexes in common bean. Analysis and comparison of the coefficient of variation of the relative values of phosphorus efficiency-related indexes in 30 common bean varieties subjected to different phosphorus treatments were identified. Plant dry matter weight, phosphorus accumulation, and acid phosphatase activity are important indexes for determining low-phosphorus tolerance. A comprehensive evaluation system for low-phosphorus tolerance in common bean was established using the fuzzy membership function method. Varieties with a composite index $\geq 0.49$ were identified as low phosphorus tolerant varieties, including "Longyun 13," "Longyun 6," and "Long173525 ," while varieties with a composite index $\leq 0.27$ were identified as varieties sensitive to low phosphorus, including "Long12-2752," "NR," and "Long15-1554."
\end{abstract}

\section{Introduction}

Common bean (Phaseolus vulgaris L.) is a self-pollinated annual diploid $(2 \mathrm{n}=2 \mathrm{x}=22)$, short-day crop (Wang et al. 2018). The seeds containing high crude fiber, carbohydrate, protein, and phospholipid are low in cholesterol, and also possess other functional components that are conducive to human health and disease prevention. Wang et al. (2018) reported have shown that eating common beans can reduce the risk of obesity, diabetes, cardiovascular disease, coloncancer, prostate cancer, and breast cancer. About $70 \%$ of the world's arable land is deficient in phosphorous (P) and thus requires phosphate fertilizer in puts (Hinsinger 2001, Kirkby and Johnston 2008). However, excessive $\mathrm{P}$ application leads to higher production costs, and the increase in the $\mathrm{P}$ price in the past decade has thus reduced farming profits. The screening and evaluation of plant varieties with low phosphorus tolerance have also been carried out in many crops, and some evaluation indexes have been established. Previous results indicated that the dry weight of the plant crown and the accumulation of $\mathrm{P}$ are important indexes for the evaluation of maize tolerance to low P (Álvaro Wrren 1992). Plant height, stem diameter, and biomass have been used as evaluation indexes in the screening of maize seedling genotypes with low $\mathrm{P}$ tolerance (Zhang et al. 2008). In a comprehensive evaluation of $\mathrm{P}$ efficiency at the soybean seedling stage, shoot and root dry weight, and shoot $\mathrm{P}$ concentration were found to be important evaluation indexes, and relative root $\mathrm{P}$ concentration was used as an auxiliary screening index (Zhang et al. 2010). The variation coefficient of the relative indexes can be used to evaluate the capacity for low-P tolerance, and characteristics with a high variation coefficient can be used as important evaluation indexes for evaluating low P tolerance (Luo 2012). At present, no studies have screened for relevant indicators of low $\mathrm{P}$ tolerance in common bean.

This present study aimed to screen low $\mathrm{P}$ tolerance indexes in common bean by analyzing and comparing the indexes related to $\mathrm{P}$ efficiency under different $\mathrm{P}$ treatments in order to establish a comprehensive evaluation system of low $\mathrm{P}$ tolerance in common bean.

\footnotetext{
*Author for correspondence: <henrymxx@163.com>.
} 


\section{Materials and Methods}

Thirty common bean varieties were obtained from the Crop Resources Institute of the Heilongjiang Academy of Agricultural Sciences (Harbin, Heilongjiang, China). A field experiment was conducted at the Minzhu Experimental Field of the Heilongjiang Academy of Agricultural Sciences $\left(45^{\circ} 49^{\prime} \mathrm{N}, 126^{\circ} 50^{`} \mathrm{E}\right)$ starting in May, 2016. The previous crop was wheat and the soil type was black soil with an organic matter content of $2.55 \%$, total nitrogen of $0.125 \%$, total P of $0.096 \%$, slow-release potassium of $836.3 \mathrm{mg} / \mathrm{kg}$, alkali hydrolyzed nitrogen of 149.63 $\mathrm{mg} / \mathrm{kg}$, available $\mathrm{P}$ of $21.56 \mathrm{mg} / \mathrm{kg}$, available potassium of $178.35 \mathrm{mg} / \mathrm{kg}$, and soil $\mathrm{pH} 6.85$. Two treatments with $\mathrm{P}$ application $(+\mathrm{P})$ and without phosphate application $(-\mathrm{P})$ were established (Table 1 ), and a complete randomized block design with three replications was used. The research plots consisted of three rows that were $5 \mathrm{~m}$ long and $0.65 \mathrm{~m}$ apart, with 175 seedlings planted in each plot. Routine management methods were adopted (Meng et al. 2010).

Table 1. Fertilization situation of each treatment.

\begin{tabular}{lccc}
\hline Treatment & $\begin{array}{c}\text { Urea } \\
(\mathrm{g} / \text { row })\end{array}$ & $\begin{array}{c}\text { Calcium_super phosphate } \\
(\mathrm{g} / \text { row })\end{array}$ & $\begin{array}{c}\text { Potassium sulphate } \\
(\mathrm{g} / \text { row })\end{array}$ \\
\hline$-\mathrm{P}$ & 12 & 0 & 12 \\
$+\mathrm{P}$ & 12 & 36 & 12 \\
\hline
\end{tabular}

Plants with consistent growth were selected and labeled after emergence. The newly grown leaves on the top of the labeled plants were cut with sterile scissors for the determination of acid phosphatase activity on the $22^{\text {nd }}$ day after emergence. The above ground parts of the other marker plants were used for the determination of dry matter weight, plant height, and total phosphorus content. The plant height was measured by a meter scale, following which the plant was dried until a constant weight at $80^{\circ} \mathrm{C}$ and then weighed to obtain the dry weight of the plant. The P content was determined by molybdenum anti monyanti colorimetry (Bao 1999). Leaf activity of acid phosphatase was carried out with an assay kit provided by Hailian Biological Company (Jiangxi, China).

Low $\mathrm{P}-$ tolerance coefficient $=$ measured value under without $\mathrm{P}$ treatment $/$ measured value under $\mathrm{P}$ treatment;

$\mathrm{P}$ accumulation $=$ dry matter weight $\times \mathrm{P}$ content.

$\mathrm{Xu}=\left(\mathrm{x}-\mathrm{x} \_\right.$min $) /\left(\mathrm{x} \_\right.$max $-\mathrm{x} \_$min $) . \mathrm{Xu}$ was the membership value, $\mathrm{X}$ is the measured value of a low P-tolerance index of each common bean variety, and $\mathrm{x}$ min and $\mathrm{x}$ max are, respectively, the minimum and maximum relative values of a certain index of all varieties.

The fuzzy membership function method is used to calculate the membership function value of each index of each variety (Feng and Guo 2014), following which the weight of the corresponding index was multiplied and then summed to obtain the weighted value of the membership function of the variety, which was then used as a composite index to evaluate low P tolerance.

Microsoft Office Excel 2003 (Microsoft Corp., Redmond, WA, USA), DPS 2.0 (TangQiyi, ZheJiang, China), and SPSS11.5 (SPSS Inc., Chicago, USA) were used for data statistics.

\section{Results and Discussion}

Phosphorus deficiency caused a decrease in the average plant height by $7.7 \%$ at 28 days after treatment (Table 2). The t-test of plant height showed significant differences in plant height between $\mathrm{P}+$ and $\mathrm{P}-\left(\mathrm{t}=2.66>\mathrm{t}_{0.05}, \mathrm{p}<0.05\right)$. Highly significant differences in the low $\mathrm{P}$ tolerance coefficient of plant height were previously detected for 76 maize varieties between a high $\mathrm{P}$ area 
and low -P area, and the variation range and coefficient of variation were large (Zhang et al. 2008). Similarly, the plant height of soybean varieties differed significantly under low-P and normal P treatments (Liu et al. 2015).

Under P condition, the average value of dry matter weight decreased by $27.4 \%$ at 28 days after treatment (Table 2). The $t$-test of dry matter weight was highly significant $(t=4.96>t 0.01, p$ $<0.01)$. The total dry matter accumulation of red kidney bean increased with the increase of nitrogen application, presenting a trend of an increase at first, followed by a decrease with the increase in P application, while increased potassium application resulted in a decrease in this index (Li 2016). The dry matter weight of soybean varieties between the low $\mathrm{P}$ and normal $\mathrm{P}$ treatments differed significantly (Liu et al. 2015).

Table 2. Effects of different phosphorus application treatments on plant height and dry matter weight at 28 days after treatment.

\begin{tabular}{|c|c|c|c|c|c|c|}
\hline \multirow[t]{2}{*}{ Item } & \multicolumn{2}{|c|}{$\begin{array}{l}\text { Plant height } \\
(\mathrm{cm})\end{array}$} & \multirow{2}{*}{$\begin{array}{c}\begin{array}{c}\text { Relative } \\
\text { value }\end{array} \\
-\mathrm{P} /+\mathrm{P}\end{array}$} & \multicolumn{2}{|c|}{$\begin{array}{l}\text { Dry matter weight } \\
(\mathrm{g})\end{array}$} & \multirow{2}{*}{$\begin{array}{c}\begin{array}{c}\text { Relative } \\
\text { value }\end{array} \\
-\mathrm{P} /+\mathrm{P}\end{array}$} \\
\hline & $-\mathrm{P}$ & $+\mathrm{P}$ & & $-\mathrm{P}$ & $+\mathrm{P}$ & \\
\hline Min & 24.36 & 26.65 & 0.85 & 0.65 & 1.43 & 0.45 \\
\hline Max & 36.85 & 38.66 & 0.97 & 2.19 & 2.55 & 0.91 \\
\hline Average & 29.66 & 32.13 & 0.92 & 1.35 & 1.86 & 0.71 \\
\hline SD & 3.47 & 3.71 & 0.03 & 0.46 & 0.31 & 0.14 \\
\hline $\mathrm{CV}$ & 11.69 & 11.54 & 3.09 & 34.29 & 16.72 & 19.32 \\
\hline
\end{tabular}

Effects of phosphorus application on phosphorus accumulation was obvious, and significant differences were detected among varieties. Comparing the low $\mathrm{P}$ tolerance coefficient of $\mathrm{P}$ accumulation, the relative $\mathrm{P}$ accumulation of "Longyun 13" was highest, followed by "Long173525" and "Englishred" (Table 3). The present results showed that P content, $\mathrm{P}$ absorption, and $\mathrm{P}$ utilization were significantly affected by different $\mathrm{P}$ concentrations. With the increase in $\mathrm{P}$ concentration, the $\mathrm{P}$ content and $\mathrm{P}$ absorption increased, while $\mathrm{P}$ utilization decreased. The response of different soybean varieties and growth stages to $\mathrm{P}$ concentration differed significantly (Ding et al. 2006). P restriction was found to significantly affect the $\mathrm{P}$ content and accumulation in sweet waxy maize, and significant differences were observed among the different varieties. Low $P$ stress was previously found to reduce the P content and accumulation in different sweet waxy maize varieties (Feng and Guo 2014)

The activity of acid phosphatase (APase) in the leaves was significantly increased under the -P treatment. Comparing the low P tolerance coefficient of activity of APase, the relative APase activity of "Longyun6" was highest, followed by "Longyun10" and "Long17-3500" (Table 4). APase is an adaptive inducible enzyme, and low P stress has an obvious induction effect on APase activity in cells. Its physiological significance may be to increase the hydrolysis of organic $\mathrm{P}$ compounds in plants to promote the reuse of $\mathrm{P}$ sources in vivo, to improve the utilization efficiency of $\mathrm{P}$ (Lopez-Arredondo et al. 2014). There were significant differences in the activity of APase in the soybean leaves between LP and NP treatments, and the ratio of APase was found to increase significantly in 32 soybean varieties (Liu et al. 2015). The APase activity in the roots and leaves of wheat increased significantly after 14 days of low P treatment (Liu et al. 2020). 
Table 3. Effects of different phosphorus application conditions on the accumulation of phosphorus at 28 days after treatment.

\begin{tabular}{|c|c|c|c|c|c|c|c|}
\hline \multirow[t]{2}{*}{ Variety } & \multicolumn{2}{|c|}{$\begin{array}{l}\text { P accumulation } \\
\text { (mg/plant) }\end{array}$} & \multirow{2}{*}{$\begin{array}{c}\begin{array}{c}\text { Relative } \\
\text { value }\end{array} \\
-\mathrm{P} /+\mathrm{P}\end{array}$} & \multirow[t]{2}{*}{ Variety } & \multicolumn{2}{|c|}{$\begin{array}{l}\mathrm{P} \text { accumulation } \\
\text { (mg/plant) }\end{array}$} & \multirow{2}{*}{$\begin{array}{c}\begin{array}{c}\text { Relative } \\
\text { value }\end{array} \\
-\mathrm{P} /+\mathrm{P}\end{array}$} \\
\hline & $-\mathrm{P}$ & $+\mathrm{P}$ & & & $-\mathrm{P}$ & $+\mathrm{P}$ & \\
\hline Longyun 3 & $2.57 \mathrm{f}$ & $5.13 b$ & $0.50 \mathrm{fgh}$ & Long17-3951 & $1.73 \mathrm{~h}$ & $3.15 \mathrm{j}$ & $0.55 \mathrm{~d}$ \\
\hline Longyun5 & $1.07 \mathrm{tu}$ & $2.85 \mathrm{~m}$ & $0.37 p$ & Long17-3952 & $1.47 \mathrm{kl}$ & $2.85 \mathrm{~m}$ & $0.51 \mathrm{ef}$ \\
\hline Longyun6 & $3.26 \mathrm{~b}$ & $5.25 \mathrm{a}$ & $0.62 \mathrm{c}$ & Long17-3957 & $1.15 \mathrm{rs}$ & $2.46 p$ & $0.47 \mathrm{ijk}$ \\
\hline Longyun 10 & $3.03 \mathrm{c}$ & $4.95 c$ & $0.61 \mathrm{c}$ & Long17-3959 & $1.18 \mathrm{qr}$ & $2.45 p$ & $0.48 \mathrm{hij}$ \\
\hline Longyun 13 & $2.82 \mathrm{~d}$ & $4.12 \mathrm{f}$ & $0.69 \mathrm{a}$ & Long17-3963 & $1.37 \mathrm{mn}$ & $2.54 \mathrm{o}$ & $0.54 \mathrm{~d}$ \\
\hline Longyun14 & $1.59 \mathrm{i}$ & $3.25 \mathrm{i}$ & 0.49ghi & Long17-3967 & $1.33 \mathrm{no}$ & $2.42 p$ & $0.55 \mathrm{~d}$ \\
\hline Japan_white & $1.56 \mathrm{ij}$ & $3.55 \mathrm{~h}$ & $0.441 \mathrm{mn}$ & Long17-4021 & $1.24 \mathrm{pq}$ & $2.33 q$ & $0.53 \mathrm{de}$ \\
\hline English_red & $3.42 \mathrm{a}$ & $5.24 \mathrm{a}$ & $0.65 b$ & Long17-4036 & $1.421 \mathrm{~m}$ & $3.01 \mathrm{k}$ & $0.47 \mathrm{ij}$ \\
\hline NV & $1.34 \mathrm{no}$ & $2.83 \mathrm{~m}$ & $0.47 \mathrm{ij}$ & Long17-4037 & $1.50 \mathrm{jk}$ & $3.55 \mathrm{~h}$ & 0.42 no \\
\hline NR & $1.11 \mathrm{rst}$ & 2.951 & $0.38 p$ & Long12-2654 & $1.18 \mathrm{qr}$ & $2.85 \mathrm{~m}$ & 0.410 \\
\hline Long17-3500 & $2.73 \mathrm{e}$ & $4.32 \mathrm{e}$ & $0.63 b c$ & Long12-2655 & $1.18 \mathrm{qr}$ & $2.76 n$ & $0.43 \mathrm{mno}$ \\
\hline Long17-3525 & $2.96 \mathrm{c}$ & $4.36 \mathrm{e}$ & $0.68 \mathrm{a}$ & Long12-2688 & $1.24 \mathrm{pq}$ & $2.75 n$ & $0.45 \mathrm{klm}$ \\
\hline Long17-3531 & $3.01 \mathrm{c}$ & $4.68 \mathrm{~d}$ & $0.64 b$ & Long12-2697 & 1.28 op & $2.77 n$ & $0.46 \mathrm{jkl}$ \\
\hline Long17-3871 & $1.92 \mathrm{~g}$ & $3.77 \mathrm{~g}$ & $0.51 \mathrm{efg}$ & Long12-2752 & $1.09 \mathrm{stu}$ & $3.04 \mathrm{k}$ & $0.36 p$ \\
\hline Long17-3897 & $1.26 \mathrm{p}$ & 2.941 & $0.43 \mathrm{mno}$ & Long15-1554 & $1.04 \mathrm{u}$ & $2.88 \mathrm{~m}$ & $0.36 \mathrm{p}$ \\
\hline
\end{tabular}

Different small letters indicate a significant difference at the $\mathrm{p}<0.05$ level.

Table 4. Effects of different phosphorus application conditions on ATPase activity at 28 days after treatment.

\begin{tabular}{|c|c|c|c|c|c|c|c|}
\hline \multirow[t]{2}{*}{ Variety } & \multicolumn{2}{|c|}{$\begin{array}{l}\text { Acid phosphatase } \\
\text { activity_(U/g) }\end{array}$} & \multirow{2}{*}{$\begin{array}{c}\begin{array}{c}\text { Relative } \\
\text { value }\end{array} \\
-\mathrm{P} /+\mathrm{P}\end{array}$} & \multirow[t]{2}{*}{ Variety } & \multicolumn{2}{|c|}{$\begin{array}{l}\text { Acid phosphatase } \\
\text { activity_(U/g) }\end{array}$} & \multirow{2}{*}{$\begin{array}{c}\begin{array}{c}\text { Relative } \\
\text { value }\end{array} \\
-\mathrm{P} /+\mathrm{P}\end{array}$} \\
\hline & $-\mathrm{P}$ & $+\mathrm{P}$ & & & $-\mathrm{P}$ & $+\mathrm{P}$ & \\
\hline Longyun3 & $1.12 \mathrm{i}$ & $1.05 \mathrm{~h}$ & 1.07fghij & Long17-3951 & $0.81 \mathrm{n}$ & 0.761 & 1.08fghi \\
\hline Longyun5 & 0.68 op & $0.65 \mathrm{~m}$ & 1.04hijkl & Long17-3952 & $1.15 \mathrm{~h}$ & $1.14 \mathrm{f}$ & $1.011 \mathrm{~m}$ \\
\hline Longyun6 & $1.75 \mathrm{a}$ & $1.27 \mathrm{a}$ & $1.37 \mathrm{a}$ & Long17-3957 & $1.08 \mathrm{j}$ & $1.05 \mathrm{~h}$ & $1.03 \mathrm{klm}$ \\
\hline Longyun 10 & $1.58 \mathrm{~b}$ & $1.25 \mathrm{~b}$ & $1.26 \mathrm{~b}$ & Long17-3959 & $0.83 n$ & 0.771 & $1.08 \mathrm{fg}$ \\
\hline Longyun 13 & $1.57 \mathrm{~b}$ & $1.28 \mathrm{a}$ & $1.23 \mathrm{bc}$ & Long17-3963 & $0.67 \mathrm{p}$ & $0.62 n$ & $1.09 \mathrm{fg}$ \\
\hline Longyun 14 & $1.03 \mathrm{k}$ & $0.96 \mathrm{j}$ & 1.07fghi & Long17-3967 & $0.93 \mathrm{~m}$ & $0.87 \mathrm{k}$ & 1.07fghij \\
\hline Japan_white & $1.22 \mathrm{fg}$ & $1.19 \mathrm{~d}$ & $1.03 \mathrm{klm}$ & Long17-4021 & $0.83 n$ & 0.761 & $1.08 \mathrm{fg}$ \\
\hline English_red & $1.43 \mathrm{~d}$ & $1.22 \mathrm{c}$ & $1.18 \mathrm{~d}$ & Long17-4036 & $0.92 \mathrm{~m}$ & $0.88 \mathrm{k}$ & $1.05 \mathrm{ghijkl}$ \\
\hline NV & $1.11 \mathrm{i}$ & $1.07 \mathrm{~g}$ & $1.04 \mathrm{ijkl}$ & Long17-4037 & $1.24 \mathrm{f}$ & $1.25 b$ & $0.99 \mathrm{~m}$ \\
\hline NR & $1.22 \mathrm{~g}$ & $1.18 \mathrm{~d}$ & $1.03 \mathrm{iklm}$ & Long12-2654 & $1.16 \mathrm{~h}$ & $1.02 \mathrm{i}$ & $1.14 \mathrm{e}$ \\
\hline Long17-3500 & $1.43 \mathrm{~d}$ & $1.16 \mathrm{e}$ & $1.24 \mathrm{bc}$ & Long12-2655 & $1.17 \mathrm{~h}$ & $1.13 \mathrm{f}$ & 1.04hijkl \\
\hline Long17-3525 & $1.44 \mathrm{~d}$ & $1.18 \mathrm{~d}$ & $1.22 \mathrm{c}$ & Long12-2688 & $1.07 \mathrm{j}$ & $1.05 \mathrm{~h}$ & $1.03 \mathrm{klm}$ \\
\hline Long17-3531 & $1.46 \mathrm{c}$ & $1.20 \mathrm{~d}$ & $1.22 \mathrm{bc}$ & Long12-2697 & $1.24 \mathrm{fg}$ & $1.22 \mathrm{c}$ & $1.011 \mathrm{~m}$ \\
\hline Long17-3871 & $1.35 \mathrm{e}$ & $1.23 \mathrm{c}$ & $1.10 \mathrm{f}$ & Long12-2752 & $0.96 \mathrm{i}$ & $0.87 \mathrm{k}$ & $1.10 \mathrm{f}$ \\
\hline Long17-3897 & $0.70 \mathrm{o}$ & $0.65 \mathrm{~m}$ & $1.08 \mathrm{fgh}$ & Long15-1554 & $1.07 \mathrm{j}$ & $1.02 \mathrm{i}$ & $1.05 \mathrm{ghijkl}$ \\
\hline
\end{tabular}

Different small letters indicate a significant difference at the $\mathrm{p}<0.05$ level. 
The low P tolerance of plants is closely related to the varietal, morphological, physiological, and biochemical characteristics of crops, and the mechanisms of low $\mathrm{P}$ tolerance differ in different plants (Ming et al. 2000, Gong et al. 2002). The results showed that plant height, dry matter weight, and $\mathrm{P}$ accumulation of different common bean varieties decreased, and the activity of acid phosphatase in the leaves increased under low-P stress, which is largely consistent with previous research results (Liu 2006, Qian et al. 2002), indicating that low P stress significantly affected the growth and development of plants and also had significant different impacts on each index.

The characteristics of the varieties exhibited some differences under the different $\mathrm{P}$ treatments, and some significant differences were detected among the different varieties. The relative value of the characters reflected the degree of influence of each treatment on the characters. The coefficient of variation is the absolute value of the variation dispersion degree of a certain index under certain conditions. The greater the coefficient of variation, the greater the difference between varieties, which can be used to reflect the low $\mathrm{P}$ tolerance of different varieties. Therefore, the relative coefficient of variation of each index can be weighted to evaluate low Pstress tolerance, and the indexes with large relative coefficient of variation values can be used as important evaluation indexes to assess low P stress capacity (Luo 2012). The results showed that plant dry matter weight, $\mathrm{P}$ accumulation, and acid phosphatase activity were more sensitive to low $P$ stress, with the variation among varieties being the largest (Table 5). Thus, these could be used as important indexes to evaluate the low $\mathrm{P}$ tolerance of common bean varieties. In some studies, the absolute values of some indexes are used to evaluate the low-P tolerance of plants (Zhang 2009). However, this approach does not account for the inherent differences among varieties, thus affecting the accuracy of the analysis results. In recent years, the relative value of indexes has often been used to screen and evaluate low P tolerance, which not only avoids the inherent differences between varieties, but also objectively evaluates the low-P tolerance of plants.

Table 5. The variability in different characteristics under low-P stress at 28 days after treatment.

\begin{tabular}{lcccc}
\hline Item & $\begin{array}{c}\text { Plant height } \\
(\mathrm{cm})\end{array}$ & $\begin{array}{c}\text { Dry matter } \\
\text { weight }(\mathrm{g})\end{array}$ & $\begin{array}{c}\text { Phosphorus accumulation } \\
(\mathrm{mg} / \mathrm{plant})\end{array}$ & $\begin{array}{c}\text { Acid phosphatase activity } \\
(\mathrm{U} / \mathrm{g})\end{array}$ \\
\hline Min & 0.85 & 0.45 & 0.36 & 0.99 \\
Max & 0.97 & 0.91 & 0.69 & 1.37 \\
Average & 0.92 & 0.71 & 0.50 & 1.10 \\
SD & 0.03 & 0.14 & 0.10 & 0.09 \\
CV/\% & 3.09 & 19.32 & 19.07 & 8.26 \\
Weight & 0.06 & 0.39 & 0.38 & 0.17 \\
\hline
\end{tabular}

The composite index reflects the low-P tolerance of a variety. The varieties for which the composite index was more than 0.49 were identified as the low-P-tolerant varieties, including "Longyun13", "Longyun6", "Long17-3525" and "Longyun10" whereas the varieties with a composite index of less than 0.27 were identified as low-P-sensitive varieties, such as "Long122752", "NR", "Long15-1554" and "Longyun 5" (Table 6).

In the present study, the coefficient of variation of the relative value of each index under lowP stress was compared and analyzed, and the results showed that the relative values of plant dry matter weight, $\mathrm{P}$ accumulation, and acid phosphatase activity were greatly affected by low-P stress. Furthermore, the variation was the largest among varieties, indicating that these could be used as 
Table 6. Low-phosphorus tolerance of common bean varieties at 28 days after treatment.

\begin{tabular}{lclc}
\hline Variety & $\begin{array}{c}\text { Composite } \\
\text { index }\end{array}$ & Variety & $\begin{array}{c}\text { Composite } \\
\text { index }\end{array}$ \\
\hline Longyun3 & 0.28 & Long17-3951 & 0.50 \\
Longyun5 & 0.19 & Long17-3952 & 0.46 \\
Longyun6 & 0.86 & Long17-3957 & 0.24 \\
Longyun10 & 0.79 & Long17-3959 & 0.25 \\
Longyun13 & 0.87 & Long17-3963 & 0.35 \\
Longyun14 & 0.44 & Long17-3967 & 0.58 \\
Japan_white_bean & 0.35 & Long17-4021 & 0.38 \\
English_red_bean & 0.78 & Long17-4036 & 0.49 \\
NV & 0.29 & Long17-4037 & 0.41 \\
NR & 0.18 & Long12-2654 & 0.40 \\
Long17-3500 & 0.77 & Long12-2655 & 0.20 \\
Long17-3525 & 0.79 & Long12-2688 & 0.27 \\
Long17-3531 & 0.77 & Long12-2697 & 0.26 \\
Long17-3871 & 0.47 & Long12-2752 & 0.18 \\
Long17-3897 & 0.21 & Long15-1554 & 0.16 \\
\hline
\end{tabular}

the main indexes for the identification and screening of low-P tolerance in common bean. Then, the fuzzy membership function method was used to calculate the membership function value of each index of each variety, and a comprehensive evaluation system was established, allowing for the screening of low-P-tolerant varieties and low-P-sensitive varieties.

\section{Acknowledgements}

The authors are grateful for financial support from the China Agriculture Research System of MOF and MARA-Food Legumes(CARS-08),the National Crop Germplasm Resources Center (NCGRC-2020-24) and the Science and technology innovation project of Science and Technology Department of Heilongjiang Province (HNK2019CX05).

\section{References}

Álvaro ES and Warren HG 1992. Screening maize inbred lines for tolerance to low-P stress condition. Plant Soil 146: 181-187.

Bao SD 1999. Soil agrochemical analysis (third edition). Beijing: China Agricul. Press 1999: 257-282.

Ding YC, Chen MC, Cheng Band Li LJ 2006. Effects of different phosphorus levels on growth and development of soybean. Shanxi Agri. Sci. 34: 47-49.

Feng EJ and Guo RF 2014. Evaluation of low phosphorus tolerance of different sweet waxy maize genotypes. Chinese J. Trop. Agric. 34: 12-17.

Gong J, Li S, Xia CL, Wang J and Li MS 2002. Screening of phosphate efficient genotypes in maize inbred lines under low phosphorus stress. Xinjiang Agric. Sci. 39: 77-81.

Hinsinger P 2001. Bioavailability of soil inorganic P in the rhizosphere as affected by root-induced chemical changes: a review. Plant Soil 237: 173-195.

Kirkby EA_and Johnston AE 2008. Soil and fertilizer phosphorus in relation to crop nutrition. Ecophysiology of plant-phosphorus interactions. Springer, Netherlands: Dordrecht, pp. 177-223. 
Li XP 2016. Effects of combined application of N, P and $\mathrm{K}$ on growth, yield and soil fertility of red kidney_bean. Shanxi: Master Thesis of Shanxi Agricultural University.

Liu CH 2006. Study on mechanism of phosphorus efficient utilization in maize with low phosphorus tolerance. Taian: Doctoral Dissertation of Shandong Agricultural University.

Liu LL, Wang JC, Yao LR, Meng YX, Li BC, Yang K, Si EJ, Wang HJ, Ma XL, Shang XW and Li XM 2020. Evaluation of low phosphorus tolerance and germplasm screening of spring wheat. Chin. J. EcoAgric. 28: 999-1009.

Liu Y, Li XH and Wang RX 2015. Screening of low phosphorus tolerance index and identification of low phosphorus tolerant soybean varieties. J. Agric. Sci. Technol. 17: 30-41.

Lopez-Arredondo DL, Leyva-Gonzalez MA, Gonzalez-Morales SI, López-Bucio J and Herrera-Estrella L 2014. Phosphate nutrition: Improving low-phosphate tolerance in crops. Annu. Rev. Plant Biol. 65: 95-123

Luo YH 2012. Screening of Maize Varieties with low nitrogen tolerance at seedling stage and preliminary study on its physiological mechanism. Yaan: Master Thesis of Sichuan Agricultural University.

Meng XX, Wang Qand Zhang W 2010. The breeding and cultivation technique of Longyundou 5. China seed industry. 4: 73.

Ming F, Mi GH, Zhang FS, Zheng XW and Zhu LH 2000. A preliminary study on genotypic differences of rice response to low phosphorus and its physiological adaptation mechanism. Appl. Environ. Biol. 6: 138-141.

Qian XG, Teng Y, WuMand Chen HY 2002. Study on barren-tolerance germplasms of maize. Seed 6: 22-24.

Wang LF, Wu J, Wang ZL, Chen JB, Yu L, Wang Q and Wang SM 2018. Phenotypic differences and ecological adaptability evaluation of common bean germplasm resources in different environments. Acta Agron. Sin. 44: 357-368.

Zhang JH, Gao SB, Yang KC, Zhang ZC, Lin HJ, Huang N, Zheng M, Xu KC, Chen YX and Pan GT 2008. Screening and identification of maize germplasm resources with low phosphorus tolerance. J. Plant Genet. Resour. 9: 335-339.

Zhang WH 2009. Study on physiological mechanism of phosphorus efficiency in Brassica napus L. Wuhan : Doctoral Dissertation of Huazhong Agricultural University.

Zhang YL, Jia JH, Zhao YQ, Gu SY and Xu JG 2010. Study on screening index of low phosphorus tolerance in soybean seedling stage. J. Anhui Agric. Sci. 38: 5506-5507. 